\title{
Extremely Polysubstituted Magnetic Material Based on Magnetoplumbite with a Hexagonal Structure: Synthesis, Structure, Properties, Prospects
}

\author{
Denis A. Vinnik ${ }^{1, *}$, Vladimir E. Zhivulin ${ }^{1}$, Evgeny A. Trofimov ${ }^{1}$, Andrey Y. Starikov ${ }^{1}$, \\ Dmitry A. Zherebtsov ${ }^{1}$, Olga V. Zaitseva ${ }^{1}$, Svetlana A. Gudkova ${ }^{1,2}$, Sergey V. Taskaev ${ }^{1,3,4}$, \\ Denis S. Klygach ${ }^{5,6}$, Maxim G. Vakhitov ${ }^{5,6}$, Elena E. Sander ${ }^{1}$, Darya P. Sherstyuk ${ }^{1}$ \\ and Alexey V. Trukhanov 1,4,7
}

1 Laboratory of Single Crystal Growth, South Ural State University (National Research University), 454080 Chelyabinsk, Russia; zhivulinve@mail.ru (V.E.Z.); tea7510@gmail.com (E.A.T);

Starikov-andrey@mail.ru (A.Y.S.); zherebtsov_da@yahoo.com (D.A.Z.); zaitcevaov@susu.ru (O.V.Z.); svetlanagudkova@yandex.ru (S.A.G.); s.v.taskaev@gmail.com (S.V.T.); vasia-ivanov-88@mail.ru (E.E.S.); daryasherstyuk77@gmail.com (D.P.S.); truhanov86@mail.ru (A.V.T.)

2 Center of shared research facilities, Moscow Institute of Physics and Technology (State University), 141701 Dolgoprudny, Russia

3 Faculty of Physics, Chelyabinsk State University, 454001 Chelyabinsk, Russia

4 Department of Electronic Materials Technology, National University of Science and Technology "MISIS", 119049 Moscow, Russia

5 Department of Design and Manufacture of Radio Equipment, South Ural State University (National Research University), 454080 Chelyabinsk, Russia; klygachds@susu.ru (D.S.K.); max_v_333@mail.ru (M.G.V.)

6 Institute of Radioelectronics and Information Technologies, Ural Federal University Named after the First President of Russia B.N. Yeltsin, 19 Mira Street, 620002 Ekaterinburg, Russia

7 Laboratory of Magnetic Films, Scientific and Practical Materials Research Centre of NAS of Belarus, 220072 Minsk, Belarus

* Correspondence: vinnikda@susu.ru; Tel.: +07-951-457-2286

Received: 1 March 2019; Accepted: 26 March 2019; Published: 6 April 2019

\begin{abstract}
Crystalline high-entropy single-phase products with a magnetoplumbite structure with grains in the $\mu \mathrm{m}$ range were obtained using solid-state sintering. The synthesis temperature was up to $1400{ }^{\circ} \mathrm{C}$. The morphology, chemical composition, crystal structure, magnetic, and electrodynamic properties were studied and compared with pure barium hexaferrite $\mathrm{BaFe}_{12} \mathrm{O}_{19}$ matrix. The polysubstituted high-entropy single-phase product contains five doping elements at a high concentration level. According to the EDX data, the new compound has a formula of $\mathrm{Ba}\left(\mathrm{Fe}_{6} \mathrm{Ga}_{1.25} \mathrm{In}_{1.17} \mathrm{Ti}_{1.21} \mathrm{Cr}_{1.22} \mathrm{Co}_{1.15}\right) \mathrm{O}_{19}$. The calculated cell parameter values were $a=5.9253(5) \AA, c=23.5257(22) \AA$, and $V=715.32(9) \AA^{3}$. The increase in the unit cell for the substituted sample was expected due to the different ionic radius of $\mathrm{Ti} / \mathrm{In} / \mathrm{Ga} / \mathrm{Cr} / \mathrm{Co}$ compared with $\mathrm{Fe}^{3+}$. The electrodynamic measurements were performed. The dielectric and magnetic permeabilities were stable in the frequency range from 2 to $12 \mathrm{GHz}$. In this frequency range, the dielectric and magnetic losses were $-0.2 / 0.2$. Due to these electrodynamic parameters, this material can be used in the design of microwave strip devices.
\end{abstract}

Keywords: high-entropy phase; magnetoplumbite structure; inorganic compounds; magnetic materials; crystal growth; crystal structure; magnetic properties

\section{Introduction}

Starting from 2010 [1], the properties of high-entropy oxide phases have been intensively studied [2-10]. Primarily, cubic oxide phases formed by divalent metals $\mathrm{Mg}, \mathrm{Co}, \mathrm{Ni}, \mathrm{Cu}$, and $\mathrm{Zn}[4,7,8]$, 
or rare earth metals were studied [9,10]. High-entropy oxide nanotubes were also reported [11], but this material is hard to consider as stable crystalline phase. Next, high-entropy phases with a more complex crystal structure-like spinel [12] or $(\mathrm{Al}, \mathrm{Cr}, \mathrm{Ti}) \mathrm{FeCoNiO}$ [13] were achieved. Two papers describe high-entropy phases with the perovskite structure [14,15].

Some researchers have studied the electrophysical and magnetic properties of high-entropy oxide phases $[3,5,6,13,16,17]$. It was shown that $\mathrm{Ti}_{x} \mathrm{FeCoNiO}_{\mathrm{y}}$ films have extremely low-electrical resistance values [17]. Some authors [3] declared an exceptionally high value of the dielectric constant of materials formed by $\mathrm{Mg}, \mathrm{Co}, \mathrm{Ni}, \mathrm{Cu}, \mathrm{Zn}, \mathrm{Li}$, and $\mathrm{Ga}$ oxides. The following studies on such materials led to the discovery of phase $(\mathrm{Mg}, \mathrm{Co}, \mathrm{Ni}, \mathrm{Cu}, \mathrm{Zn})_{1-\mathrm{x}-\mathrm{y}} \mathrm{Ga}_{\mathrm{y}} \mathrm{A}_{\mathrm{x}} \mathrm{O}$ (with $\mathrm{A}=\mathrm{Li}, \mathrm{Na}, \mathrm{K}$ ) with high-ionic conductivity, which makes them promising for use as solid electrolytes [5] that could be obtained as a thin film [16]. A recently published paper aimed to generalize the theoretical description of high-entropy phase stability [18].

Still, there were no reports on high-entropy oxide materials with the magnetoplumbite structure $\mathrm{PbFe}_{12} \mathrm{O}_{19}$, which are widely used in modern technology thanks to a combination of its electrophysical and magnetic properties [19-26].

Traditionally, the barium and strontium hexaferrites have been explored as the parent phases in which iron atoms are replaced by a certain amount of one or two other elements. The introduction of dopants makes it possible to manage the electrical and magnetic properties of the resulting phase. This opens up the possibility of obtaining materials whose electrical and magnetic characteristics exactly correspond to the requirements of electronic devices [19]. Synthesis of high-entropy phases with the magnetoplumbite structure can be considered as the next step in obtaining substituted structures, which allow regulating the properties of materials in wider limits [27].

This work is devoted to studying the possibility of synthesizing a high-entropy phase with a magnetoplumbite structure, whose composition can be described as $\mathrm{BaFe}_{6}(\mathrm{Ti}, \mathrm{Co}, \mathrm{In}, \mathrm{Ga}, \mathrm{Cr})_{6} \mathrm{O}_{19}$, studying its structure, and magnetic and electrophysical properties.

\section{Materials and Methods}

The set of elements used for the synthesis was selected on the basis of the following considerations. For the parent " $\mathrm{BaB}_{12} \mathrm{O}_{19}$ " structure, the doping elements of " $\mathrm{B}$ " type include Ti and In (that both proved to have a high ability to substitute iron $[28,29])$, and the elements that have similar ionic radii- $-\mathrm{Ga}, \mathrm{Co}$, and $\mathrm{Cr}$ (Table 1$)$.

Table 1. The radii of B-type ions (CN6, low/high spin state) [30].

\begin{tabular}{cccccccc}
\hline $\mathbf{B}$ & $\mathbf{I n}^{3+}$ & $\mathrm{Ga}^{3+}$ & $\mathbf{C r}^{3+}$ & $\mathbf{F e}^{2+}$ & $\mathbf{T i}^{4+}$ & $\mathbf{F e}^{3+}$ & $\mathbf{C o}^{3+}$ \\
\hline ionic radii $(\mathrm{pm})$ & 79 & 62 & 61.5 & $61 / 77$ & 60.5 & $55 / 64.5$ & $52.5 / 61$ \\
\hline
\end{tabular}

In the target composition, half of the atoms of the " $\mathrm{B}$ " type were iron atoms, and the second half consisted of doping elements in equimolar concentrations. The configurational entropy of mixing in this case was lower than for the case when the concentrations of all elements, including iron, were equal. Thus, for the $\mathrm{Ba}\left(\mathrm{Fe}_{2} \mathrm{Ti}_{2} \mathrm{Co}_{2} \mathrm{In}_{2} \mathrm{Ga}_{2} \mathrm{Cr}_{2}\right) \mathrm{O}_{19}$ phase, the configurational entropy of mixing would be equal to $1.792 \mathrm{R}$, whereas for our composition, $\mathrm{Ba}\left(\mathrm{Fe}_{6} \mathrm{Ti}_{1.2} \mathrm{Co}_{1.2} \mathrm{In}_{1.2} \mathrm{Ga}_{1.2} \mathrm{Cr}_{1.2}\right) \mathrm{O}_{19}$ was $1.498 \mathrm{R}$.

However, reducing the iron content below that of $\mathrm{Ba}\left(\mathrm{Fe}_{6} \mathrm{Ti}_{1.2} \mathrm{Co}_{1.2} \mathrm{In}_{1.2} \mathrm{Ga}_{1.2} \mathrm{Cr}_{1.2}\right) \mathrm{O}_{19}$ led to the disappearance of useful electrophysical and magnetic properties of the material obtained. Therefore, the composition under study represents a compromise between the need to preserve the magnetic characteristics of magnetoplumbite and to obtain a sufficiently high-configurational entropy.

The solid-state sintering was used for crystalline high-entropy single-phase with a magnetoplumbite structure. The $\mathrm{BaCO}_{3}, \mathrm{Fe}_{2} \mathrm{O}_{3}, \mathrm{TiO}_{2}, \mathrm{In}_{2} \mathrm{O}_{3}, \mathrm{Ga}_{2} \mathrm{O}_{3}, \mathrm{Cr}_{2} \mathrm{O}_{3}$, and $\mathrm{CoO}$ (Russia, Yekaterinburg, Ural plant) were used as initial charge components. The mixture was ground in an agate mortar and filled into a 30-mL platinum crucible. Table 2 presents the initial weight ratios of charge compositions. The synthesis temperature that provides the single-phase formation was up to $1400{ }^{\circ} \mathrm{C}$. The synthesis time was up to $5 \mathrm{~h}$. 
The sample morphology and chemical composition were investigated using a scanning electron microscope, Jeol JSM7001F (Tokyo, Japan), with an energy dispersive spectrometer, Oxford INCA $\mathrm{X}$-max 80, for elemental analysis. Average composition and deviation were measured from 5-7 single-phase areas from each sample.

Table 2. Initial weight ratios of charge compositions (wt.\%).

\begin{tabular}{ccccccccc}
\hline$\#$ & Target Composition & $\mathbf{B a C O}_{3}$ & $\mathbf{F e}_{2} \mathbf{O}_{3}$ & $\mathbf{T i O}_{2}$ & $\mathbf{I n}_{2} \mathbf{O}_{3}$ & $\mathbf{G a}_{2} \mathbf{O}_{3}$ & $\mathbf{C r}_{2} \mathbf{O}_{3}$ & $\mathbf{C o O}$ \\
\hline 1 & $\mathrm{BaFe}_{12} \mathrm{O}_{19}$ & 17.078 & 82.922 & - & - & - & - & - \\
2 & $\mathrm{Ba}\left(\mathrm{Fe}_{6} \mathrm{Ga}_{1.2} \mathrm{In}_{1.2} \mathrm{Ti}_{1.2} \mathrm{Cr}_{1.2} \mathrm{Co}_{1.2}\right) \mathrm{O}_{19}$ & 16.013 & 38.873 & 7.777 & 13.517 & 9.126 & 7.400 & 7.296 \\
\hline
\end{tabular}

X-ray powder diffraction analyses were performed on a diffractometer Rigaku Ultima IV (Tokyo, Japan) in the 2 Theta angular range from $10^{\circ}$ to $80^{\circ}$ with the speed of $2^{\circ} / \mathrm{min}$. For this purpose, the samples were thoroughly powdered and then applied on a thin layer of single-crystalline silicon.

For the electrodynamic properties determination, the powder particles of the studied material had a size of no more than $0.1 \mathrm{~mm}$. Due to this, the space between the outer and inner conductors of a filled coaxial line segment and the probability of void appearance, which may affect the measured parameters, decreased. The test material in the coaxial line was clamped on both sides, with polystyrene rings. More details about the measurement technique can be read elsewhere [31].

Since the values of polystyrene permittivity and permeability in the frequency range $2-12 \mathrm{GHz}$ are $\varepsilon \sim 1.1$ and $\mu \sim 1$ [32], their influence can be neglected in further calculations.

To account for the influence of polystyrene rings on the measured S-parameters, the following measurements were performed:

- $\quad$ measuring S-parameters of the air-filled coaxial line with polystyrene rings;

- measuring S-parameters of the material-filled coaxial line with polystyrene rings.

When filling the coaxial line segment with samples of the material, the weight of the filling substance was controlled. The weight of the studied samples was $7.3 \pm 0.1 \mathrm{~g}$.

The use of a powder material makes it possible not to make samples of a certain shape, but to fill the volume required for measurement with a fine-grained structure.

When measuring S-parameters of the coaxial line with the test material as a dielectric, a dual-port (Thru-Reflect-Line) TRL-calibration was applied. Calibration Kit RPC-N, $50 \Omega$, LRL Version manufactured by Rosenberger (Tittmoning, Germany), an additional airline (type N Beadless Air Line) 2553T15 manufactured by Maury (Ontario, California, USA), and measuring adapters were used as calibration standards. Measurement was performed using a single-port vector reflectometer CABAN 180-02 (Chelyabinsk, Russia).

To calculate the dielectric and magnetic permeability, the following measurements were made. In the first dimension, a segment of the coaxial line with the material was connected to the reflectometer, a load was set at the other end of the segment. In this case, measurements were made of the real and imaginary parts of the input resistance. Then, instead of the matched load, a short circuit was established, and the real and imaginary parts of the input resistance was measured.

\section{Results}

This section provides a concise and precise description of the experimental results of the morphology, chemical composition, crystal structure, magnetic, and electrodynamic properties investigation.

\subsection{Morphology and Chemical Composition}

The obtained crystalline high-entropy single-phase products with a magnetoplumbite structure were obtained within the $\mu \mathrm{m}$-range grains. Typical SEM images of the free surfaces of the samples (Figure 1) illustrate the sizes and shapes of the crystals. Presumably, the hexagonal-shaped crystals 
can be associated with a magnetoplumbite phase. For all samples, the EDX analysis of 10 individual hexagonal crystals and sample areas was performed. The chemical composition and average sample formulas are given in Table 3. The special procedure was used for sample preparation for quantitative SEM/EDX analysis. To improve the measurement accuracy, the sample powders were applied to the holder and flattened with a glass. The standard deviations of the analyses were up to $5 \%$.
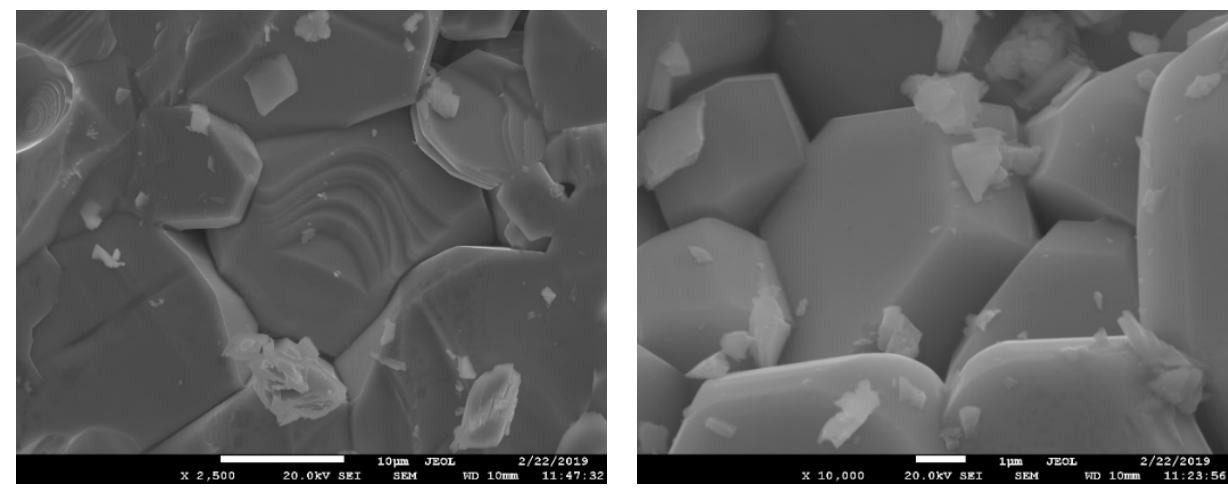

Figure 1. SEM images of a high-entropy sample with a magnetoplumbite structure.

Table 3. The chemical composition and average sample formulas.

\begin{tabular}{|c|c|c|c|c|c|c|c|c|}
\hline \multirow{2}{*}{$\#$} & \multicolumn{7}{|c|}{ Chemical Composition, wt. \% } & \multirow{2}{*}{ Sample Formula } \\
\hline & Ba & $\mathrm{Fe}$ & $\mathrm{Ti}$ & In & $\mathrm{Ga}$ & $\mathrm{Cr}$ & Co & \\
\hline 1 & 3.36 & 38.90 & - & - & - & - & - & $\mathrm{BaFe}_{12} \mathrm{O}_{19}$ \\
\hline 2 & 3.45 & 19.28 & 3.91 & 3.78 & 4.06 & 3.94 & 3.71 & $\mathrm{Ba}\left(\mathrm{Fe}_{6} \mathrm{Ga}_{1.25} \mathrm{In}_{1.17} \mathrm{Ti}_{1.21} \mathrm{Cr}_{1.22} \mathrm{Co}_{1.15}\right) \mathrm{O}_{19}$ \\
\hline
\end{tabular}

\subsection{Crystal Structure}

From the PXRD data, it was concluded that the high-entropy sample was the single magnetoplumbite phase with the general formula $\mathrm{BaFe}_{6} \mathrm{M}_{6} \mathrm{O}_{19}$ ( $\mathrm{M}$ - sum of dopant cations). The single-phase sample pattern is shown in Figure 2. The space group was established. The substituted sample and initial matrix have the same space group $\mathrm{P} 6(3) / \mathrm{mmc}$. Calculated unit cell parameters of experimental pure matrix $\mathrm{BaFe}_{12} \mathrm{O}_{19}$, high-entropy sample $\mathrm{Ba}\left(\mathrm{Fe}_{6} \mathrm{Ga}_{1.25} \mathrm{In}_{1.17} \mathrm{Ti}_{1.21} \mathrm{Cr}_{1.22} \mathrm{Co}_{1.15}\right) \mathrm{O}_{19}$, and literature data are presented in Table 3. 


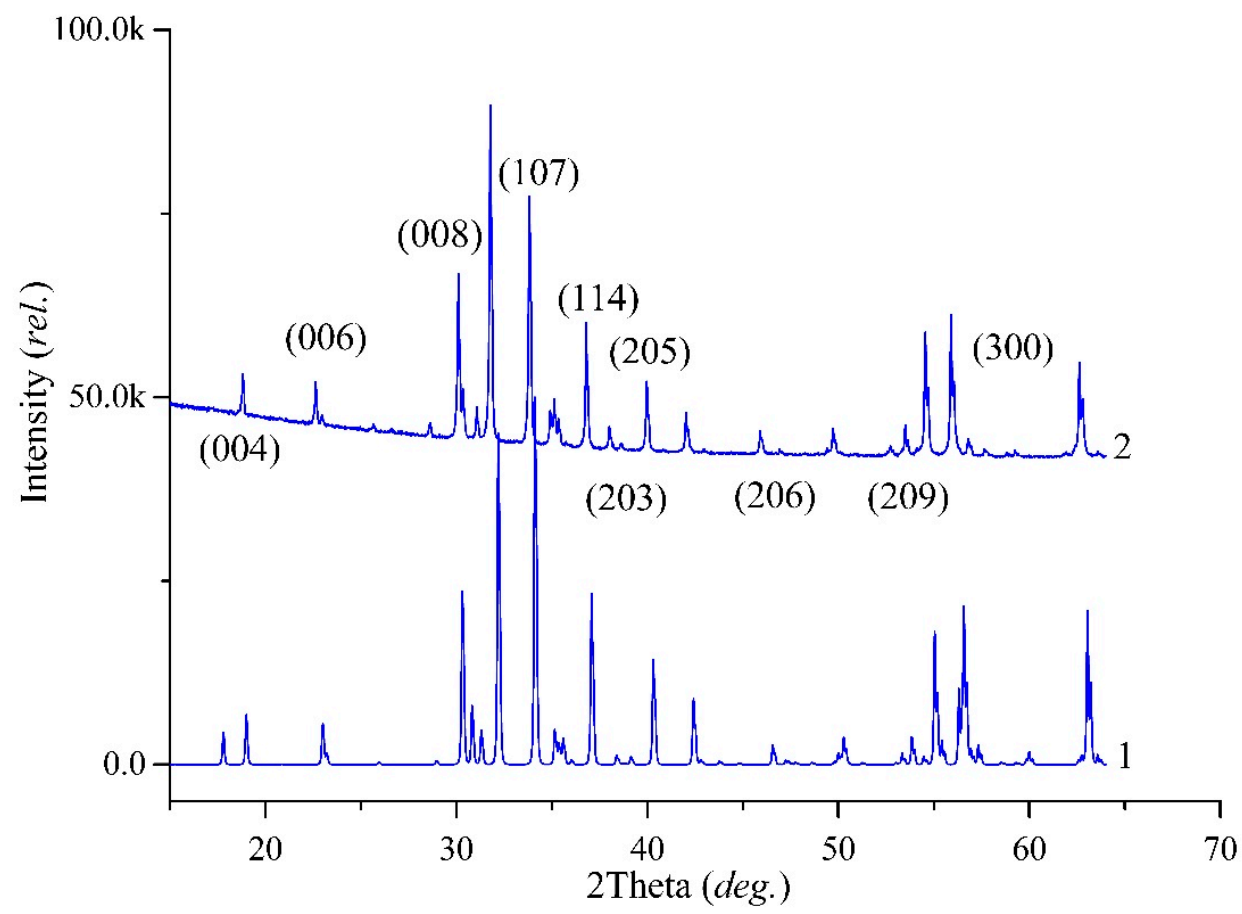

Figure 2. Powder XRD patterns: 1-simulated according to crystal structure data in the literature [33]; 2 - experimental sample of $\mathrm{Ba}\left(\mathrm{Fe}_{6} \mathrm{Ga}_{1.25} \mathrm{In}_{1.17} \mathrm{Ti}_{1.21} \mathrm{Cr}_{1.22} \mathrm{Co}_{1.15}\right) \mathrm{O}_{19}$. Differences arose due to the minor variations in intensities according to the high-substitution levels of $\mathrm{Fe}$ by $\mathrm{Ti} / \mathrm{In} / \mathrm{Ga} / \mathrm{Cr} / \mathrm{Co}$ and mostly different degrees in the preferred orientation of the grains.

Unit cell determination from powder diffraction (Table 4) already indicated a substitution influence of $\mathrm{Fe}$ by $\mathrm{Ti} / \mathrm{In} / \mathrm{Ga} / \mathrm{Cr} / \mathrm{Co}$. Due to the different ionic radius of $\mathrm{Ti} / \mathrm{In} / \mathrm{Ga} / \mathrm{Cr} / \mathrm{Co}$ compared with $\mathrm{Fe}^{3+}\left(\mathrm{r}\left(\mathrm{Fe}^{3+}\right)=0.55 \AA ; \mathrm{r}\left(\mathrm{Ti}^{4+}\right)=0.605 ; \mathrm{r}\left(\mathrm{In}^{3+}\right)=0.80 \AA ; \mathrm{r}\left(\mathrm{Ga}^{3+}\right)=0.62 \AA ; \mathrm{r}\left(\mathrm{Cr}^{3+}\right)=0.615 \AA\right.$; $\mathrm{r}\left(\mathrm{Co}^{2+}\right)=0.73 \AA$ with $\left.\mathrm{CN}=6[30]\right)$, and an increasing unit cell with dopants appearing was expected.

Table 4. Calculated unit cell parameters of barium hexaferrite.

\begin{tabular}{ccccc}
\hline No. & Synthesis Method & $\boldsymbol{a}[\AA \mathbf{\AA}]$ & $\boldsymbol{c}[\AA \mathbf{\AA}]$ & $\boldsymbol{V}\left[\AA^{3}\right]$ \\
\hline$[31]$ & $\mathrm{BaFe}_{12} \mathrm{O}_{19}$ & 5.893 & 23.194 & 697.5 \\
1 & $\mathrm{BaFe}_{12} \mathrm{O}_{19}$ & $5.8922(1)$ & $23.1953(6)$ & $697.40(2)$ \\
2 & $\mathrm{Ba}\left(\mathrm{Fe}_{6} \mathrm{Ga}_{1.25} \mathrm{In}_{1.17} \mathrm{Ti}_{1.21} \mathrm{Cr}_{1.22} \mathrm{Co}_{1.15}\right) \mathrm{O}_{19}$ & $5.9253(5)$ & $23.5257(22)$ & $715.32(9)$ \\
\hline
\end{tabular}

\subsection{Electrodynamic Properies}

The results of measuring the real and imaginary parts of the dielectric permittivity of the frequency of the samples of materials are present in Figures 3 and 4. Sample 1 is initial matrix $\mathrm{BaFe}_{12} \mathrm{O}_{19}$ and Sample 2 is substituted sample $\mathrm{Ba}\left(\mathrm{Fe}_{6} \mathrm{Ga}_{1.25} \mathrm{In}_{1.17} \mathrm{Ti}_{1.21} \mathrm{Cr}_{1.22} \mathrm{Co}_{1.15}\right) \mathrm{O}_{19}$ (numbers 1 and 2 at Tables 2-4). 


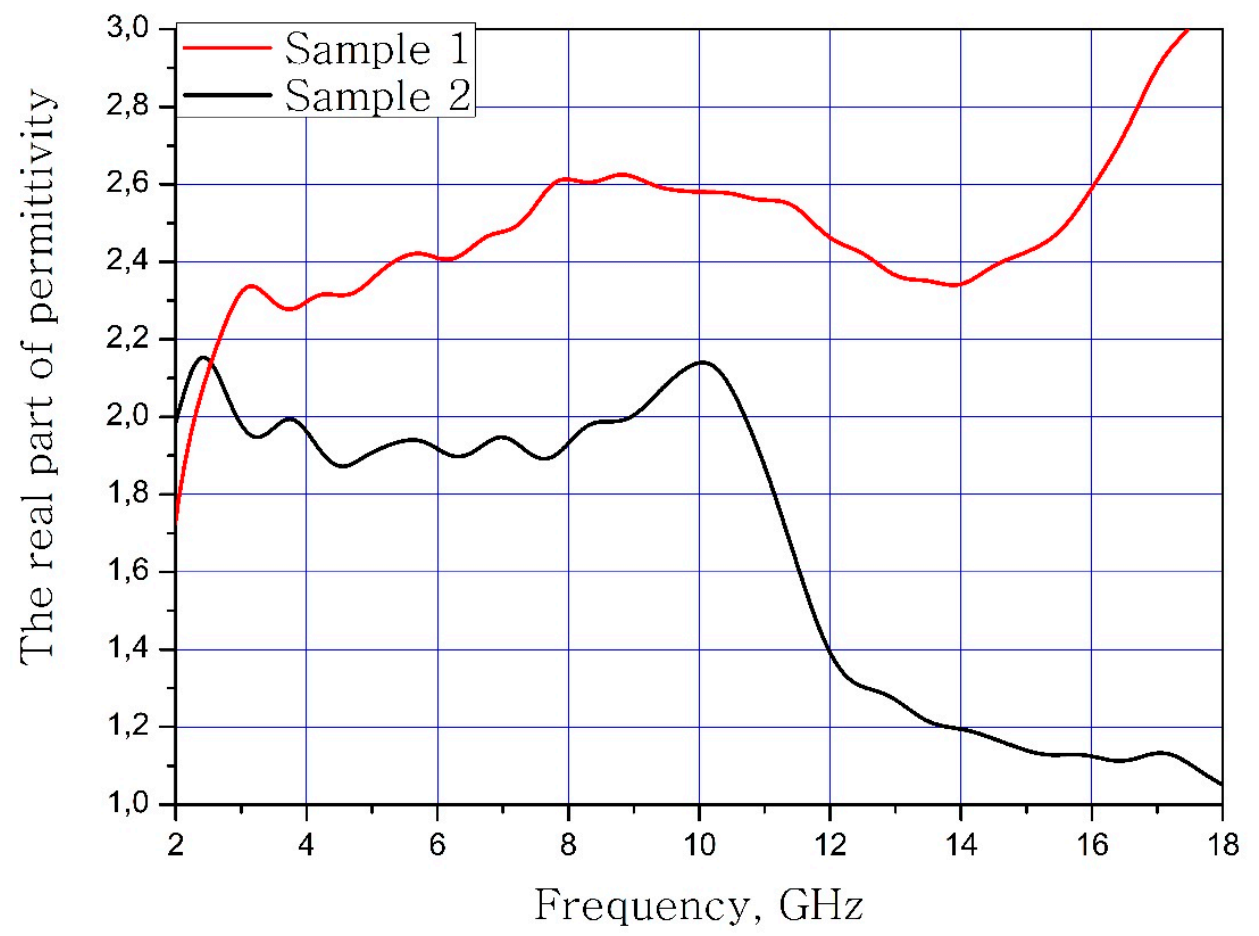

Figure 3. Frequency dependence of the real part of the dielectric permittivity of the samples.

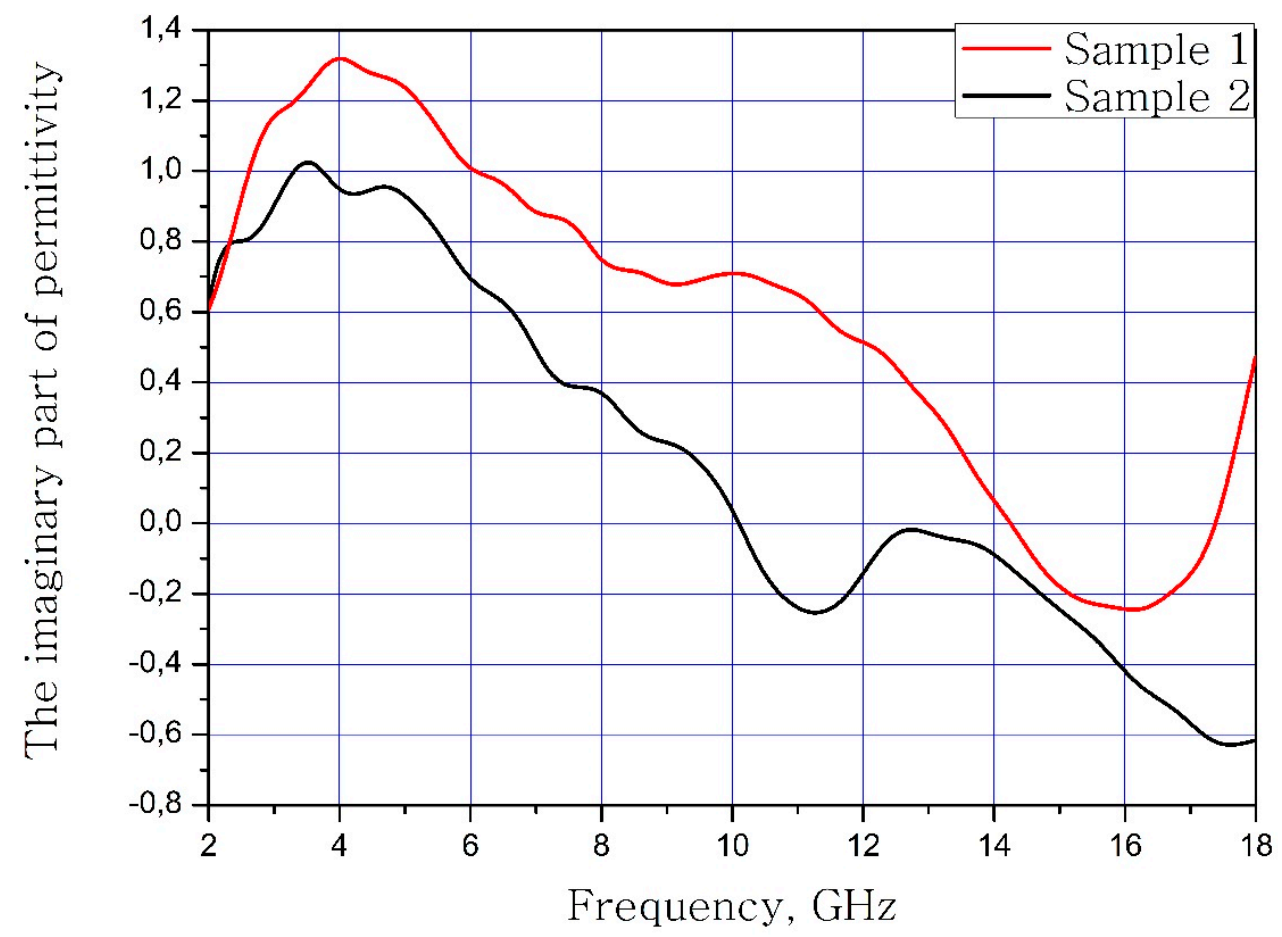

Figure 4. Frequency dependence of the imaginary part of the dielectric permittivity of the samples.

The results of calculations of the dependence of the real and imaginary parts for magnetic permeability on the frequency of the material samples are present in Figures 5 and 6. 


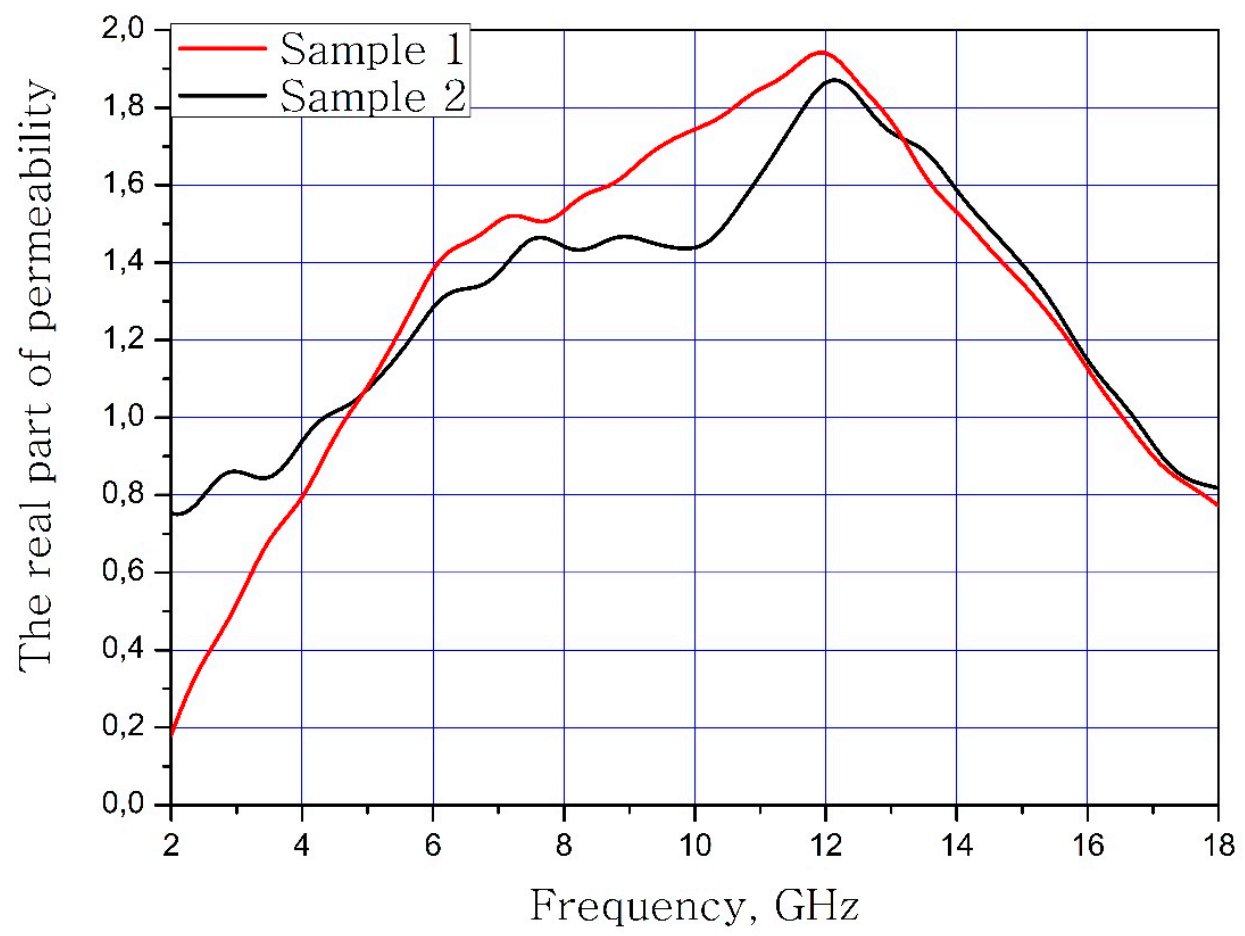

Figure 5. Frequency dependence of the real part of the magnetic permeability of the samples.

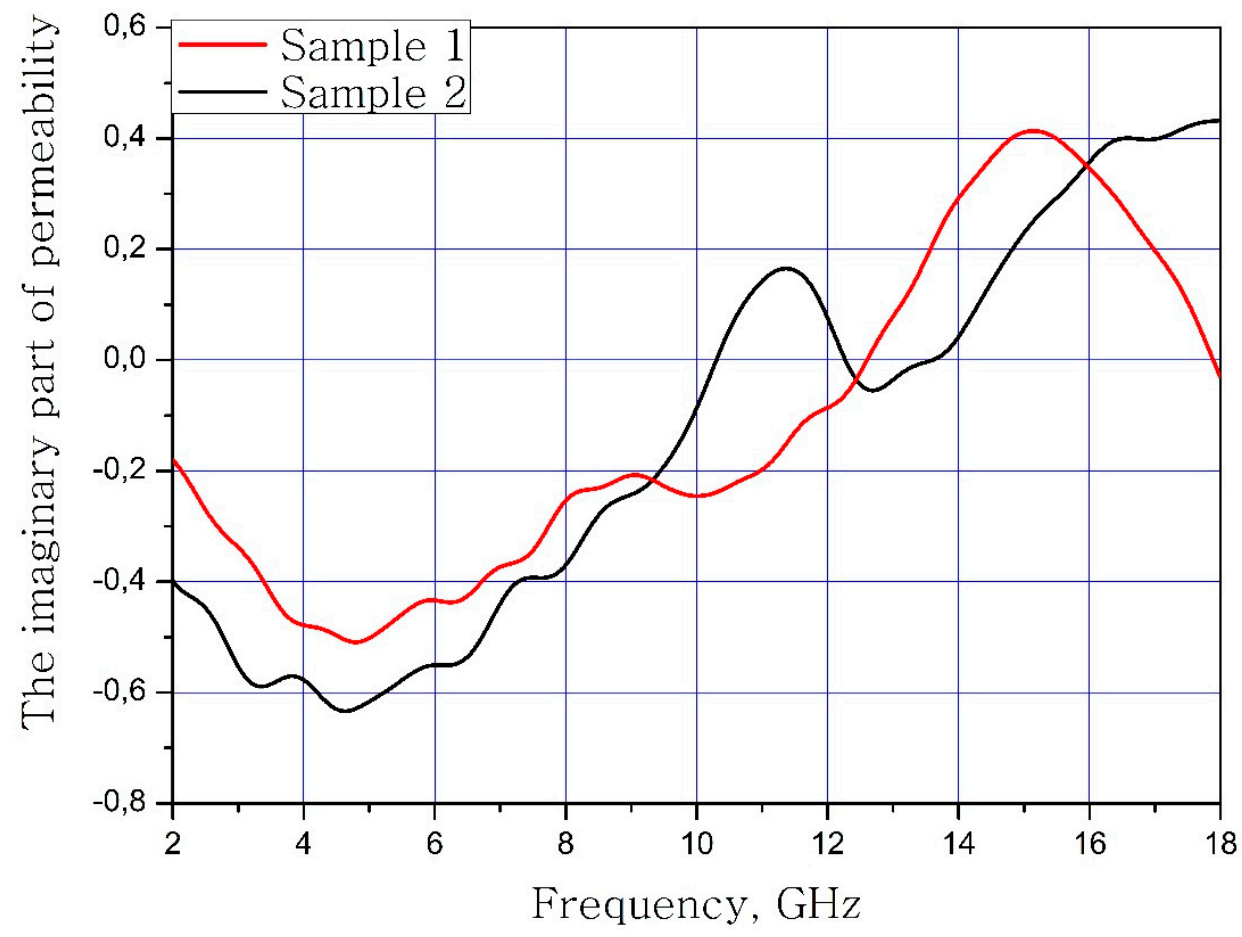

Figure 6. Frequency dependence of the imaginary part of magnetic permeability of samples.

The calculated dependences of the electric loss tangent and magnetic loss tangent on the frequency of the material samples are present in Figures 7 and 8. 


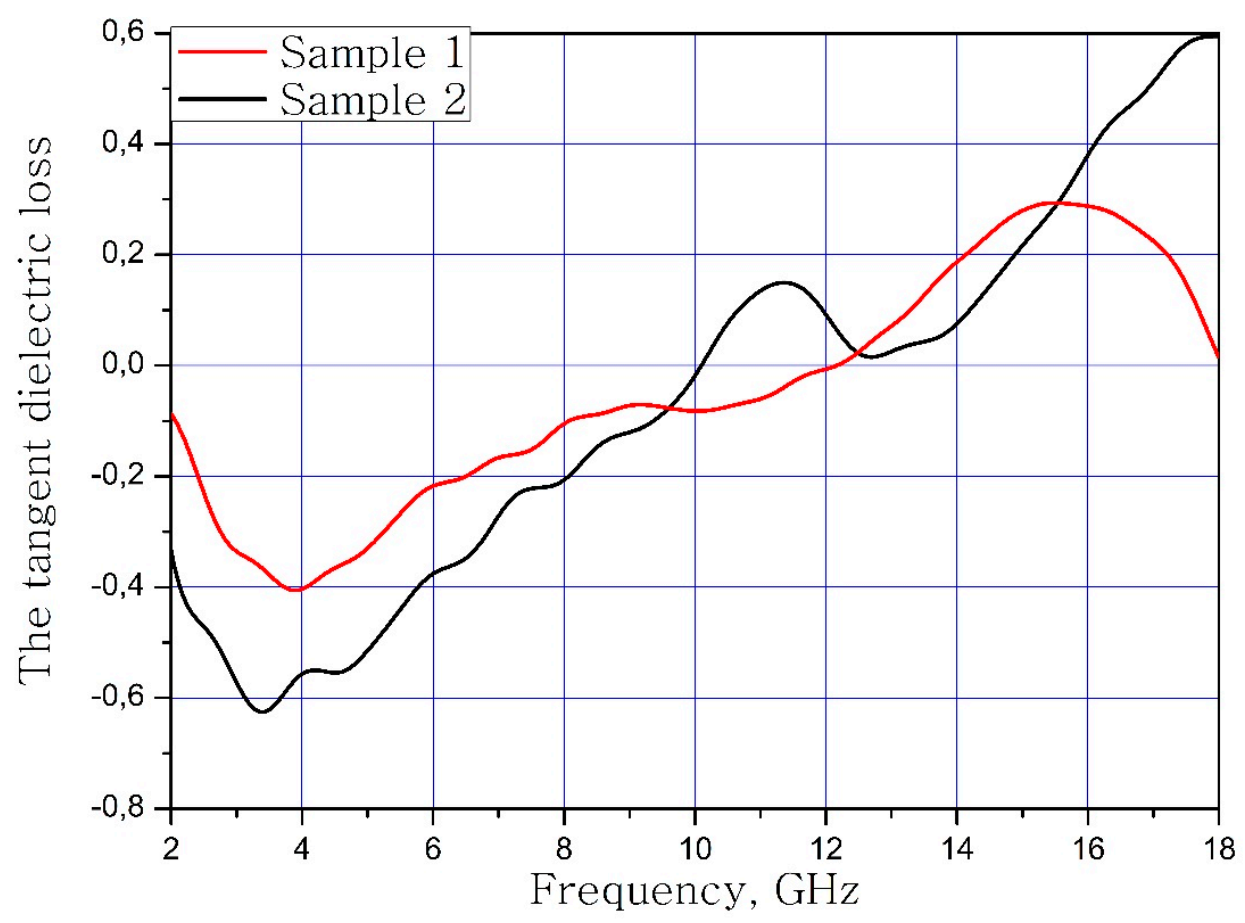

Figure 7. Frequency dependence of the dielectric loss tangent of samples.

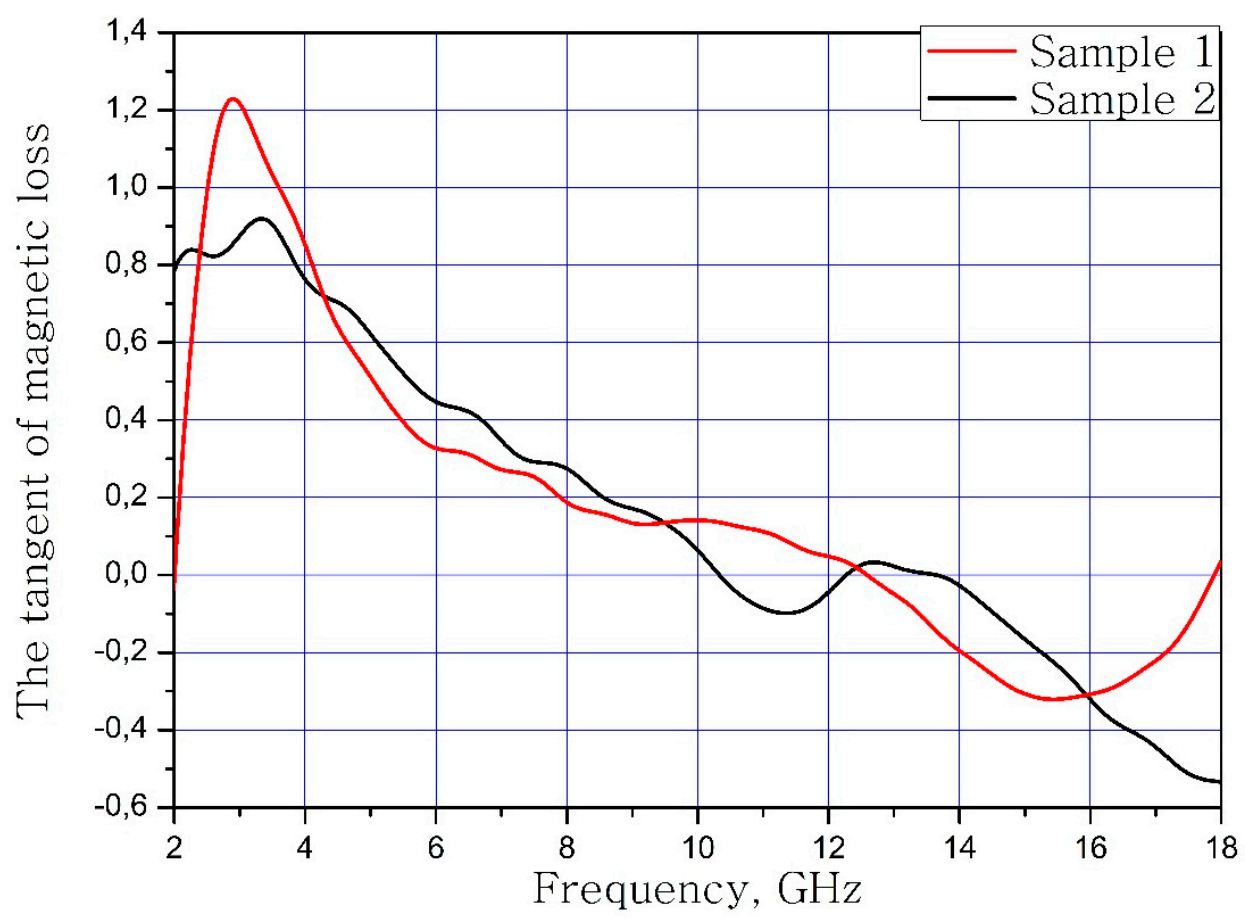

Figure 8. Frequency dependence of the tangent of magnetic loss samples.

The calculated dependences of the skin layer on the frequency of the material samples are present in Figure 9. 


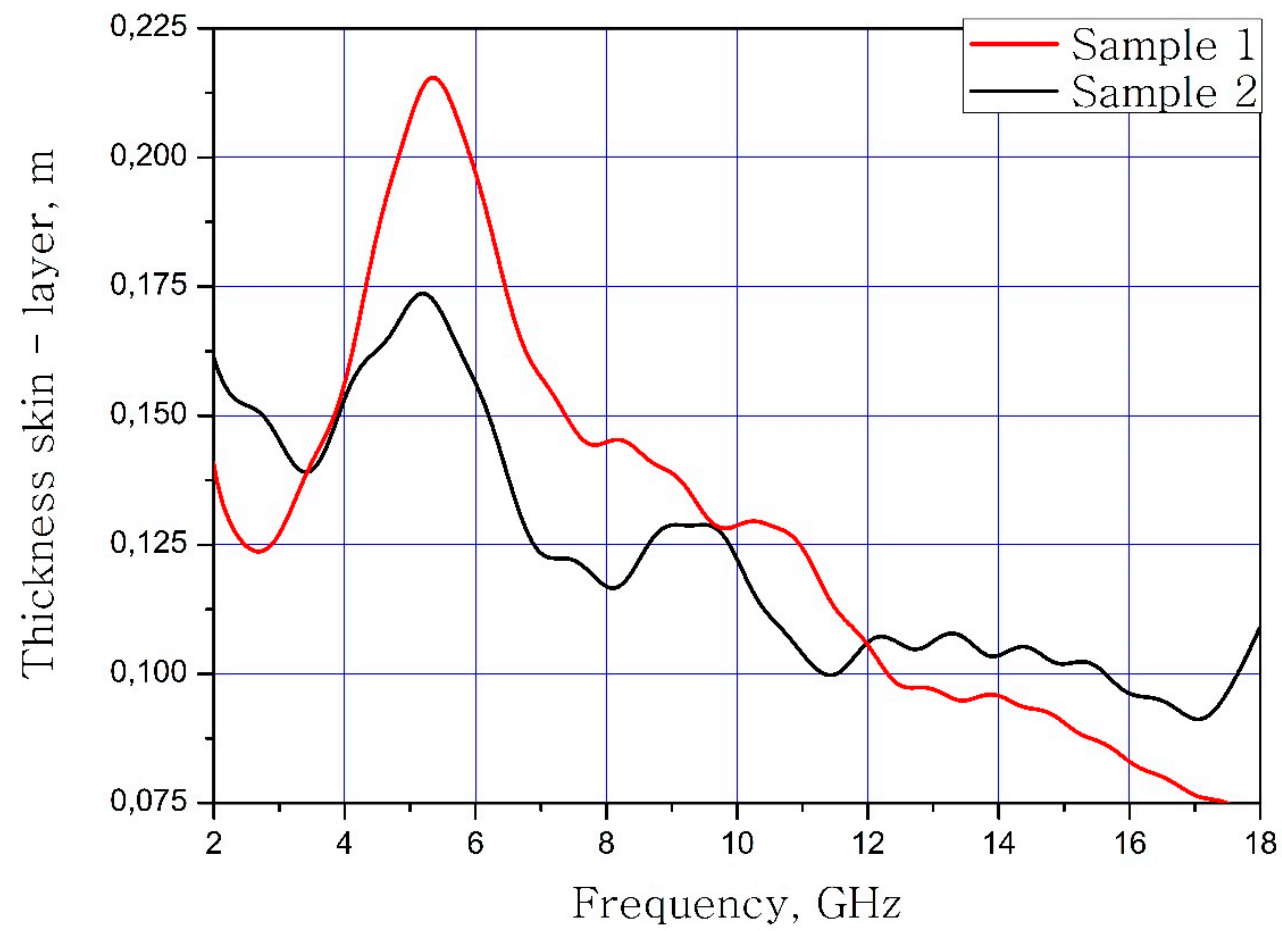

Figure 9. The frequency dependence of the thickness of the skin layer of samples.

It can be concluded that the electrodynamic parameters' change in the polysubstituted material was not significant. In the frequency range from 10 to $18 \mathrm{GHz}$, the real part of the dielectric permittivity decreased for the $\mathrm{Ba}\left(\mathrm{Fe}_{6} \mathrm{Ga}_{1.25} \mathrm{In}_{1.17} \mathrm{Ti}_{1.21} \mathrm{Cr}_{1.22} \mathrm{Co}_{1.15}\right) \mathrm{O}_{19}$ and increased for the $\mathrm{BaFe}_{12} \mathrm{O}_{19}$. The real and imaginary parts of the magnetic permeability have now significant changed and are very close for both samples. The dielectric loss tangents for these samples almost coincide, but the increase in losses at low and high frequencies should be noted for the substituted sample. The decrease in the thickness of the skin layer for the polysubstituted material was due to the increase in dielectric and magnetic losses (Figures 7-9).

\section{Conclusions}

In the present work, a high-entropy single-phase product with a magnetoplumbite structure was obtained. The calculated brutto formula of substituted phase was $\mathrm{Ba}\left(\mathrm{Fe}_{6} \mathrm{Ga}_{1.25} \mathrm{In}_{1.17} \mathrm{Ti}_{1.21} \mathrm{Cr}_{1.22} \mathrm{Co}_{1.15}\right) \mathrm{O}_{19}$. From the PXRD data it was concluded that the high-entropy sample was the single magnetoplumbite phase. The increased cell parameters values of the substituted sample were observed. The calculated cell parameter values were $a=5.9253(5) \AA$ and $V=715.32(9) \AA^{3}$. The electrodynamic investigation was performed. The dielectric and magnetic permeabilities were stable in the frequency range from 2 to $12 \mathrm{GHz}$. In this frequency range, the dielectric and magnetic losses were $-0.6 / 1.2$. Due to these electrodynamic parameters, this material can be used in the design of microwave strip devices.

Author Contributions: E.A.T., O.V.Z., V.E.Z., and D.A.Z. conceived and designed the experiments; V.E.Z., O.V.Z., D.P.S., E.E.S., and A.Y.S. performed the experiments; S.A.G. and A.V.T. contributed to the powder XRD measurements; S.V.T. contributed to the properties' measurements; D.S.K. and M.G.V. contributed electrodynamic measurements; D.A.V. wrote the paper.

Funding: The work was supported by the Russian Science Foundation, project No. 18-73-10049.

Conflicts of Interest: The authors declare no conflict of interest.

\section{References}

1. Lin, M.I.; Tsai, M.H.; Shen, W.J.; Yeh, J.W. Evolution of structure and properties of multi-component (AlCrTaTiZr)O $\mathrm{O}_{\mathrm{x}}$ films. Thin Solid Films 2010, 518, 2732-2737. [CrossRef] 
2. Rost, C.M.; Sachet, E.; Borman, T.; Moballegh, A.; Dickey, E.C.; Hou, D.; Jones, J.L.; Curtarolo, S.; Maria, J.P. Entropy-stabilized oxides. Nat. Commun. 2015, 6, 8485. [CrossRef]

3. Bérardan, D.; Franger, S.; Dragoe, D.; Meena, A.K.; Dragoe, N. Colossal dielectric constant in high entropy oxides. Rapid Res. Lett. 2016, 10, 328-333. [CrossRef]

4. Sarkar, A.; Djenadic, R.; Usharani, N.J.; Sanghvi, K.P.; Chakravadhanula, V.S.K.; Gandhi, A.S.; Hahn, H.; Bhattacharya, S.S. Nanocrystalline multicomponent entropy stabilised transition metal oxides. J. Eur. Ceram. Soc. 2017, 37, 747-754. [CrossRef]

5. Berardan, D.; Franger, S.; Meena, A.K.; Dragoe, N. Room temperature lithium superionic conductivity in high entropy oxides. J. Mater. Chem. A 2016, 4, 9536-9541. [CrossRef]

6. Rak, Z.; Rost, C.M.; Lim, M.; Sarker, P.; Toher, C.; Curtarolo, S.; Maria, J.-P.; Brenner, D.W. Charge compensation and electrostatic transferability in three entropy-stabilized oxides: Results from density functional theory calculations. J. Appl. Phys. 2016, 120, 095105. [CrossRef]

7. Rost, C.M.; Rak, Z.; Brenner, D.W.; Maria, J.-P. Local structure of the $\mathrm{Mg}_{\mathrm{x}} \mathrm{Ni}_{\mathrm{x}} \mathrm{Co}_{\mathrm{x}} \mathrm{Cu}_{\mathrm{x}} \mathrm{Zn} \mathrm{n}_{\mathrm{x}} \mathrm{O}(\mathrm{x}=0.2)$ entropy-stabilized oxide: An EXAFS study. J. Am. Ceram. Soc. 2017, 100, 2732-2738. [CrossRef]

8. Berardan, D.; Meena, A.K.; Franger, S.; Herrero, C.; Dragoe, N. Controlled Jahn-Teller distortion in (MgCoNiCuZn)O-based high entropy oxides. J. Alloys Compd. 2017, 704, 693-700. [CrossRef]

9. Sarkar, A.; Loho, C.; Velasco, L.; Thomas, T.; Bhattacharya, S.S.; Hahn, H.; Djenadic, R.R. Multicomponent equiatomic rare earth oxides with narrow band gap and associated praseodymium multivalency. Dalton Trans. 2017, 46, 12167-12176. [CrossRef]

10. Djenadic, R.; Sarkar, A.; Clemens, O.; Loho, C.; Botros, M.; Chakravadhanula, V.S.K.; Kübel, C.; Bhattacharya, S.S.; Gandhi, A.S.; Hahn, H. Multicomponent equiatomic rare earth oxides. Mater. Res. Lett. 2017, 5, 102-109. [CrossRef]

11. Lei, Z.; Liu, X.; Li, R.; Wang, H.; Wu, Y.; Lu, Z. Ultrastable metal oxide nanotube arrays achieved by entropy-stabilization engineering. Scr. Mater. 2018, 146, 340-343. [CrossRef]

12. Dąbrowa, J.; Stygar, M.; Mikuła, A.; Knapik, A.; Mroczka, K.; Tejchman, W.; Danielewski, M.; Martin, M. Synthesis and microstructure of the $(\mathrm{Co}, \mathrm{Cr}, \mathrm{Fe}, \mathrm{Mn}, \mathrm{Ni})_{3} \mathrm{O}_{4}$ high entropy oxide characterized by spinel structure. Mater. Lett. 2018, 216, 32-36. [CrossRef]

13. Tsau, C.H.; Hwang, Z.Y.; Chen, S.K. The Microstructures and Electrical Resistivity of (Al,Cr,Ti)FeCoNiO High-Entropy Alloy Oxide Thin Films. Adv. Mater. Sci. Eng. 2015, 2015, 353140. [CrossRef]

14. Jiang, S.; Hu, T.; Gild, J.; Zhou, N.; Nie, J.; Qin, M.; Harrington, T.; Vecchio, K.; Luo, J. A new class of high-entropy perovskite oxides. Scr. Mater. 2018, 142, 116-120. [CrossRef]

15. Sarkar, A.; Djenadic, R.; Wang, D.; Hein, C.; Kautenburger, R.; Clemens, O.; Hahn, H. Rare earth and transition metal based entropy stabilized perovskite type oxides. J. Eur. Ceram. Soc. 2018, 38, 2318-2327. [CrossRef]

16. Meisenheimer, P.B.; Kratofil, T.J.; Heron, J.T. Giant Enhancement of Exchange Coupling in Entropy-Stabilized Oxide Heterostructures. Sci. Rep. 2017, 7, 13344. [CrossRef]

17. Tsau, C.-H.; Yang, Y.-C.; Lee, C.-C.; Wu, L.-Y.; Huang, H.-J. The Low Electrical Resistivity of the High-entropy Alloy Oxide Thin Films. Procedia Eng. 2012, 36, 246-252. [CrossRef]

18. Anand, G.; Wynn, A.P.; Handley, C.M.; Freeman, C.L. Phase stability and distortion in high-entropy oxides. Acta Mater. 2018, 146, 119-125. [CrossRef]

19. Pullar, R.C. Hexagonal ferrites: A review of the synthesis, properties and applications of hexaferrite ceramics. Prog. Mater. Sci. 2012, 57, 1191-1334. [CrossRef]

20. Zhang, W.; Peng, B.; Zhang, W.; Zhou, S.; Schmidt, H. Ultra large coercivity in barium ferrite thin films prepared by magnetron sputtering. J. Magn. Magn. Mater. 2010, 322, 1859-1862. [CrossRef]

21. Xu, H.; Zhang, W.; Peng, B.; Zhang, W. Properties of barium hexa-ferrite thin films dependent on sputtering pressure. Appl. Surf. Sci. 2011, 257, 2689-2693. [CrossRef]

22. Song, Y.-Y.; Ordóñez-Romero, C.L.; Wu, M. Millimeter wave notch filters based on ferromagnetic resonance in hexagonal barium ferrites. Appl. Phys. Lett. 2009, 95, 142506. [CrossRef]

23. Harris, V.G. Modern microwave ferrites. IEEE Trans. Mag. 2012, 48, 1075-1104. [CrossRef]

24. Cho, H.S.; Kim, S.S. M-Hexaferrites with planar magnetic anisotropy and their application to high-frequency microwave absorbers. IEEE Trans. Magn. 1999, 35, 3151-3153. [CrossRef]

25. Matsumoto, M.; Miyata, Y.A. Gigahertz-range electromagnetic wave absorber with wide bandwidth of hexagonal ferrite. J. Appl. Phys. 1996, 79, 5486-5488. [CrossRef] 
26. Ghasemi, A.; Hossienpour, A.; Morisako, A.; Liu, X.; Ashrafizadeh, A. Investigation of the microwave absorptive behavior of doped barium ferrites. Mater. Des. 2008, 29, 112-117. [CrossRef]

27. Zaitseva, O.V.; Vinnik, D.A.; Trofimov, E.A. The Poly-Substituted M-Type Hexaferrite Crystals Growth. Mater. Sci. Forum 2019, 946, 186-191. [CrossRef]

28. Vinnik, D.A.; Klygach, D.S.; Zhivulin, V.E.; Malkin, A.I.; Vakhitov, M.G.; Gudkova, S.A.; Galimov, D.M.; Zherebtsov, D.A.; Trofimov, E.A.; Knyazev, N.S.; et al. Electromagnetic properties of $\mathrm{BaFe}_{12} \mathrm{O}_{19}$ :Ti at centimeter wavelengths. J. Alloys Compd. 2018, 755, 177-183. [CrossRef]

29. Trukhanov, S.V.; Trukhanov, A.V.; Turchenko, V.A.; Trukhanov, A.V.; Tishkevich, D.I.; Trukhanova, E.L.; Zubar, T.I.; Karpinsky, D.V.; Kostishyn, V.G.; Panina, L.V.; et al. Magnetic and dipole moments in indium doped barium hexaferrites. J. Magn. Magn. Mater. 2018, 457, 83-96. [CrossRef]

30. Shannon, R.D.; Prewitt, C.T. Effective Ionic Radii in Oxides and Fluorides. Acta Cryst. Sect. B 1969, 25, 925-946. [CrossRef]

31. Klygach, D.S.; Vakhitov, M.G.; Vinnik, D.A.; Bezborodov, A.V.; Gudkova, S.A.; Zhivulin, V.E.; Zherebtsov, D.A.; SakthiDharan, C.P.; Trukhanov, S.V.; Trukhanov, A.V.; et al. Measurement of permittivity and permeability of barium hexaferrite. J. Magn. Magn. Mater. 2018, 465, 290-294. [CrossRef]

32. Knott, E.F. Dielectric constant of plastic foams. IEEE Trans. Antennas Propag. 1993, 41, 1167-1171. [CrossRef]

33. Townes, W.D.; Fang, J.H.; Perrotta, A.J. The crystal structure and refinement of ferromagnetic barium ferrite, $\mathrm{BaFe}_{12} \mathrm{O}_{19}$. Z. Kristallogr. 1967, 125, 437-449. [CrossRef]

(C) 2019 by the authors. Licensee MDPI, Basel, Switzerland. This article is an open access article distributed under the terms and conditions of the Creative Commons Attribution (CC BY) license (http://creativecommons.org/licenses/by/4.0/). 